\title{
CGMP-Dependent Protein Kinase 1
}

National Cancer Institute

\section{Source}

National Cancer Institute. cGMP-Dependent Protein Kinase 1. NCI Thesaurus. Code C125497.

cGMP-dependent protein kinase 1 (671 aa, $76 \mathrm{kDa}$ ) is encoded by the human PRKG1 gene. This protein is involved in nitric oxide/cyclic GMP-dependent signal transduction. 